\title{
Introduction
}

\section{Frugal Innovation and Development Research}

\author{
André Leliveld ${ }^{\mathrm{a}, *}$ and Peter Knorringa ${ }^{\mathrm{b}}$ \\ ${ }^{a}$ African Studies Centre Leiden, Centre for Frugal Innovation in Africa, Leiden University, Leiden, \\ The Netherlands. \\ b International Institute for Social Studies, Centre for Frugal Innovation in Africa, Erasmus University \\ Rotterdam, Rotterdam, The Netherlands. \\ E-mail: knorringa@iss.nl
}

*E-mail: a.h.m.leliveld@asc.leidenuniv.nl

\begin{abstract}
This article sets the scene for a special issue on why frugal innovations are increasingly important for development research. While the top-down business and management literature on frugal innovation has claimed developmental relevance, we give at least equal importance to much longerstanding bottom-up development studies discourses on grass-root innovation, bricolage, and livelihood strategies. We argue that we need both literatures for a better understanding of how frugal innovations relate to development. Accordingly, we position the articles in this special issue in the frugal innovation and development debate. Finally, we discuss the relevance of a frugal innovation lens in how two major global trends are impacting upon global development opportunities: the global diffusion of 3rd and 4th Industrial Revolution digital technologies and global population dynamics. We consider these two trends to be major entries for future research on frugal innovation and development.
\end{abstract}

Cet article pose le décor pour un numéro spécial sur les raisons pour lesquelles les innovations frugales sont de plus en plus importantes pour la recherche sur le développement. Tandis que la littérature "topdown" du monde des affaires et de la gestion au sujet de l'innovation frugale a revendiqué une pertinence dans le monde du développement, nous donnons au moins autant d'importance aux messages bien plus anciens, portés par les études "bottom-up "sur le développement, à propos d'innovation à base communautaire, de bricolage et de stratégies de subsistance. Par conséquent, nous placerons les articles de ce numéro spécial dans le débat sur l'innovation frugale et le développement. Nous soutiendrons que nous avons besoin des deux littératures pour mieux comprendre comment les innovations frugales sont liées au développement. En outre, nous discuterons brièvement de la pertinence d'adopter une perspective d'innovation frugale dans l'analyse de la façon dont deux grandes tendances mondiales impactent les opportunités de développement international : la diffusion mondiale des technologies de la 3ème et 4ème révolution industrielle et la dynamique démographique mondiale. Nous considérions ces deux tendances comme thèmes majeurs pour de futures recherches en matière de innovations frugales et développement.

The European Journal of Development Research (2018) 30, 1-16.

https://doi.org/10.1057/s41287-017-0121-4; published online 21 November 2017

Keywords: frugal innovation; development; digital technologies; 4th Industrial Revolution; population dynamics; Bottom of the Pyramid; Global South

\section{Frugal Innovation: Definition and Potential Developmental Relevance}

While several definitions of frugal innovation exist in the literature, there is consensus that it encompasses (re)designing products, services, systems, and business models in order to reduce complexity and total lifecycle costs, and enhance functionality, while providing high user value and affordable solutions for relatively low-income customers, the latter being either consumers 
or business in both the Global South and North (Bhatti, 2012, Rao, 2013, Tiwari et al, 2016, Zeschky et al, 2011, 2014). It is important to note that this definition leaves open whether such frugal innovations are produced by either large or smaller businesses or by community members themselves. Moreover, it leaves open whether such innovations are developed by businesses as a commercial proposition to sell to the so-called Bottom of the Pyramid, or by community members to address local constraints and deal with acute scarcity. The other crucial point to take on board in the definition is that frugality is not an absolute all-or-nothing concept, but a matter of degree and interpretation, like inclusion or sustainability. Frugal innovations do also not automatically contribute to (inclusive or sustainable) development; for us, it is an empirical question whether they do so. For example, many of the frugal innovations for really short-term solutions (like cheap batteries or solar cells produced in Asia and sold in rural Africa) may qualify as frugal innovation on some indicators - low cost, affordable, functional and may help to address short-term issues, but it is an open question to what extent these also contribute to longer-term developmental solutions for poor communities.

Point of departure in this special issue is that the phenomenon of frugal innovation can most usefully be studied as a specific innovation practice, which can be found at different levels of society involving many and diverse actors, who interact in various configurations. Issues of power and conflict continue to be of crucial importance in how such frugal innovation practices impact on people's lives. We will argue in this editorial that the business and management discourse, and the development discourse, analyze at least partially overlapping practices in real life, even though they emphasize different parts of the narrative. Looking at frugal innovation through a development lens brings the localized innovation practices of poor people themselves to the forefront and makes it possible to link the discussion to a long history of thought in development studies on the role of innovation, technology, and bricolage in survival and livelihood strategies. In doing so, the necessity is shown to engage in a closer examination of what the phenomenon of frugal innovation is, what its dynamics are, and what its developmental relevance can be. In a recent article, Knorringa et al (2016) set out some first ideas for examining the dynamics and potentials of frugal innovation for development. The present special issue aims to take this endeavor further, by presenting articles which discuss empirical case studies as well as delve into more theoretically grounded debates about frugal innovation and its potential developmental relevance.

This remainder of this editorial addresses the following issues. First, we introduce two discourses informing the current frugal innovation and development debate and how they come together in real life: the discourse in innovation and business management literature on the 'discovery' of the hidden fortunes at the Bottom or Base of the Pyramid (BoP), and the discourse to be found in the development studies literature on the developmental relevance of localized and embedded bottomup innovations by usually poor individuals, households, and communities. ${ }^{1}$ Next, we position the contributions to the special issue within these discourses and highlights their contribution to the frugal innovation and development debate and agenda. Thereafter we introduce two global trends, the diffusion of digital technologies and population dynamics, and we will briefly discuss how a frugal innovation lens on these major trends can contribute to future research on frugal innovation and development. The final section contains the concluding remarks.

\section{Frugal Innovation and the BoP Hype}

A major discourse that has sparkled the interest of development scholars for frugal innovation originates from the Bottom of the Pyramid (BoP) discourse in innovation management and 
business organization literature in the early 2000s. This discourse suggests that corporate business can find fortune by serving the BoP, those living on less than US \$2 a day, an estimated 4 billion people worldwide, who would constitute a mega and still unsaturated market of 'micro consumers' and are underserved by existing products and services (Prahalad and Hall, 2002). To serve BoP markets successfully requires a different kind of products and services. They should be considerably cheaper, maintain (technological) functionality, affordable to low-income customers, and applicable in resource-constrained environments (Bhatti, 2012). It was The Economist (2010) that coined the term 'frugal' to refer to the Indian practice of Jugaad innovation, a colloquial Hindi and Punjabi word used to signify creativity, and a 'make do' attitude in daily life to respond to limitations in resources, whether financial, material, or institutional (Radjou et al, 2012, Radjou and Prabhu, 2015).

Examples range from Unilever's well-known small washing powder sachets and Nokia's low-end mobile phones for the African market, to Tata's affordable water purifying device and cheap solar energy mini-grids for electricity. But also the Nano Car, which costs $\$ 2000$ and is built and produced in India, is considered by some to be a frugal innovation. Although the majority of the estimated four billion BoP consumers lives in the Global South, they can also be found in the Global North, notably in countries which were hit by the financial crisis and subsequent economic recession in the 2000s (USA, South European countries) and in countries in transition. Frugal innovation was in first instance presented as a business proposition for corporates to develop products, services, or systems with which they could reach out to unsaturated markets.

Initially, the basic principle behind frugal innovation in management studies language has been 'doing more with less' (Radjou et al, 2012). This principle is increasingly replaced by 'doing better with less' (Radjou and Prabhu 2015), presenting frugal innovation as a win-win socially responsible business proposition that combines high turnovers and profits with realizing development goals. This discourse resonates in academic research on 'inclusive business for the poor' (alternatively 'social business,' 'pro-poor business,' or 'inclusive capitalism') which has started to address questions such as how to marry profits with social aims, assuming that 'business activities can contribute to the long-term goal of poverty alleviation by embedding the neglected poor parts of the world population into efficient value chains and market structures' (Hahn, 2012, p. 51).

\section{Frugal Innovation and Development Studies}

The above discourse and its proposition has met with severe criticism and skepticism by development scholars (Bhaduri, 2016; Dolan, 2013; Dolan and Rajak, 2016; Meagher and Lindell, 2013, Meagher in this special issue) by questioning among others the (normative) assumption that designing and producing goods or services for low-income people is equal to solving their developmental problems. Their critique is rooted in a discourse, which has a long history in development studies. For example, Kaplinsky (2011) observes that in the informal sector literature is has been shown already for decades that small-scale and locally owned firms are key providers of tailor made products and services for low-income consumers. Many of these products and services are the result of long-term experiments and innovative practices in which frugality is key given the resource-constrained environments in which such practices take place. Moreover, many if not most of these incremental innovations in local settings are carried out by individuals, households, and communities - i.e., not by firms - and are not driven by commercial incentives but are part of people's bricolage (Lévi-Strauss, 1962) and survival 
and livelihood strategies (Chambers and Conway, 1992; Ellis, 2000; De Haan and Zoomers, 2005; Scoones, 2009), or grassroots innovations (Seyfang and Smith, 2007). So, more often than not, frugal innovation comes from the cumulative effect of implementing small-scale ideas over prolonged periods of time. It is a process that encompasses the acts of numerous individuals, not only the original inventors but also the producers, consumers, and middlemen that transmit and operationalize the innovations, making them acceptable to society (Gewald et al, 2012). (Frugal) Innovation in this sense thus refers to processes of invention, adoption, adaptation, appropriation, and transformation - not only of products but also of systems, and not only scientific and technological products and systems, but including all institutional, organizational, social, and political dimensions (see also Bhatti, 2012).

In addition, Bhaduri (2016) refers to a significant rise in interest among academic scholars in recognizing informal economic spheres as reservoirs of knowledge, skills, and creativity (Obeng-Odoom and Ameyaw, 2014), next to the traditional focus on its exploitative working conditions. Regarding the innovative practices in the informal sector, it is also noteworthy - as also observed by Kaplinsky (2011) - to refer to the literature and thinking on appropriate technology in the 1970s and 1980s, which received a great stimulus by Schumacher's publication 'Small is Beautiful' (Schumacher, 1973), in which notions of frugality can be traced as well. A main open issue for development studies to address is that these initiatives and the local innovative practices by the poor themselves have for a long time been 'below the radar' (Kaplinsky, 2011) of theories on innovation, technology, and economic growth in lowincome settings (Kaplinsky, 2011, Chataway et al, 2014, Bhaduri, 2016). A step forward for development studies could be to re-visit the vast amount of literature written on technological capabilities in the Global South (Fransman and King, 1984) and acquiring more formal technological capabilities (Lall, 1992), on learning and innovation systems in developing countries (Lundvall et al, 2011), and the numerous empirical survival and livelihoods studies. A critical reflection through a frugal innovation lens at their theoretical underpinnings and empirical findings and connect this more systematically to new interpretations of frugal innovations in more informal settings may gain more insight into the factors which determine the success or failure of these frugal innovations (Leliveld, 2017).

The often less visible frugal and grassroots innovations at local level may potentially offer quite good development opportunities and strengthening inclusivity, but one needs to be careful to not romanticize solidarity and like-mindedness. A key challenge with many of the more localized and embedded innovations is also the issue of scaling. Policy makers and entrepreneurs are, for different reasons, inherently motivated to try and scale successful experiments. However, from an inclusion perspective, one needs to be careful to not try and replicate and/or multiply successful bottom-up practices indiscriminately. After all, they are usually highly context-specific, and when started by local individuals or communities, often did not have any such scaling or commercial incentive at the outset. Moreover, scaling may mean that the activity becomes economically (much) more attractive, which may well lead to processes that exclude initial participants and attracts new more wealthy actors.

\section{Two Worlds Meet}

We showed that in the BoP literature, frugal innovation has become synonymous with often top-down innovation practices by large companies, trying to expand their markets to include poor and 'new middle class' consumers with stripped-down versions of existing products and services. We also showed that a second set of literatures starts by recognizing and valuing the 
developmental relevance of localized and embedded bottom-up innovations by usually poor individuals, households, and communities. In these literatures, frugal innovations are practices by local people to use predominantly locally available means to overcome acute constraints in survival and livelihood strategies. While these two sets of literatures have not engaged much, in real life, these are less and less separate 'worlds.' For example, Pedersen and McCormick (1999) explained how business systems in Africa were bifurcated between a small 'modern' formal business sector and a massive informal sector in the late 1990s; however, nowadays these two worlds are far less separate. Multinational companies, increasingly also from countries like China, India, and Brazil, are targeting relatively poorer and 'new middle class' consumers, not solely with first-generation frugal innovations of stripped-down products, services, and systems, but increasingly also experimenting with new business models and distribution systems to expand their market reach.

Such experiments with new models are further facilitated by the increased global diffusion of technological capabilities through various forms of 'polycentric innovation,' which designates the global integration of specialized research and development capabilities across multiple regions to create novel solutions that no single region or company could have completely developed on its own (Radjou, 2009). This polycentric innovation is also thought particularly important for designing and producing frugal products and services. As Nakata and Weidner (2012) observe, the living conditions of poor people must be taken into account, including issues such as income poverty, social stigmatization, inadequate housing, infrastructural services, and remote locations. In addition, 'the poor' also highly segmented in terms of income, and comprises multiple cultures, ethnicities, literacy, capabilities, and needs (Prahalad, 2012). The challenge is, therefore, not just simply providing stripped-down versions of products to middle- and high-income consumers, but instead providing newly designed, and value and context sensitive innovations that are truly compatible with the circumstances of people living in poverty (Nakata and Weidner, 2012).

In theory, this could give agency and a competitive advantage to innovators in local communities and local (informal) economies, because they possess (often tacit) knowledge about the unique local circumstances, local preferences, and needs. A strategy by corporate business involved in designing, producing, and marketing frugal innovations is therefore to engage local innovators and entrepreneurs in polycentric innovation and business networks, to be able to tap into this valuable knowledge. However, little is known about the entrepreneurial opportunities this offers for domestic firms. On the one hand, there is an optimistic view that polycentric innovation can indeed lead to more chances for domestic firms; on the other hand, there is a critical view that points out possible crowding out or exploitation of (informal) domestic firms (see Knorringa et al, 2016). Both views lack empirical evidence though when it comes to the Global South.

In sum, multinationals are increasingly penetrating informal economies and previously more remote and isolated communities with frugal innovations; local activists, NGOs, and social entrepreneurs increasingly attempt to bring local (frugal) innovation practices to scale. This leads to new and different economic and social configurations in which these two worlds meet, generating different outcomes in terms of power, (in)equalities, and development. A frugal innovation angle to development research is well positioned to critically explore the interactions and conflicts between informal and formal actors and various bodies of knowledge, and to identify under what conditions such innovation processes are more likely to contribute to more inclusive developmental outcomes. For this, we need a critical multidisciplinary approach to frugal innovation practices as well as an empirical approach (Knorringa et al, 2016) to which 
the articles in this special issue aim to contribute. The next section will position the several articles in this special issue in the frugal innovation and development debate.

\section{The Contributions in this Special Issue}

This special issue starts with two articles which critically discuss the frugal innovation discourse in relation to (inclusive) development. In the first article, Meagher argues from a political economy perspective that the frugal innovation models informed by the BoP discourse tend to treat informal economies as a pool of workers and organizational resources to be tapped for the benefit of external innovators, rather than as economic systems in their own right. Therewith, her article goes to the heart of the discussion on the potential effects of new economic and social configurations that result from frugal innovation, and related business models adopted by corporate business to reach out to the BoP. Meagher argues that these frugal innovation models ignore the realities of informal economies as organized systems with distinctive economic interests and dynamics of accumulation. According to Meagher, existing frugal innovation models for the BoP are as much about power as about inclusion, and raise new questions about the motives and terms of inclusion. Shifting costs and risks onto local agents and poor customers produces a form of frugality that looks more like adverse incorporation and accumulation by dispossession, than complementarity or genuine inclusion. Frugal innovation would only become a source of empowerment for informal actors when they have real influence over innovation processes and the distribution of gains across profits, wages, and pricing at the BoP.

The idea that frugal innovations and related business models are not politically neutral, nor by definition inclusive, is also central to the article by Vossenberg, in which she presents an analytical framework rooted in feminist theory that could help to assess the effects of frugal innovations on three key developmental outcomes which are relevant to women: empowerment, enhanced wellbeing, and gender equality. The key focus is on exploring when frugal innovations are more likely to reproduce or transform institutionalized gender-related constraints that structure how men and women can access resources and opportunities. She applies the conceptual framework to the existing case of MoneyMaker, a low-cost foot pedaled micro-irrigation pump, showing that earlier conclusions on the inclusiveness of this frugal innovation are contradictory when looked upon through a gender lens. Vossenberg's article is a plea to use and to build upon existing feminist and gender studies in development to generate more gender sensitive analyses on the developmental outcomes of frugal innovations.

The conceptual debates in the first two articles are followed by a set of case studies on frugal innovations which run from more qualitative to more quantitative. Peša's article investigates the transformational potential of mobile money (which is generally considered to be a frugal innovation) in Kitwe in Zambia, with a focus on the agents and tellers who play a crucial role in scaling mobile money. Like Meagher's article, she focuses on the implications of the interaction between formal and informal realities for local actors. Some inclusion of local actors takes places, notably for mobile money agents, but often at quite unfavorable conditions and with little prospects of upward mobility in mobile money value chains. The conclusion is that the presence of mobile financial services has not merely spurred entrepreneurship and economic growth, but has equally resulted in casual labor conditions and informalization. Existing power structures and inequalities have remained, expressed in the discrepancy between agents and tellers. 
The article by Devi and Kumar departs from the idea that frugal innovation - as also indicated in the previous sections - is an incremental process which involves many actors. Their argument is that we need Actor Network Theory (ANT) to better understand the processes behind frugal innovations in the informal sector. They apply ANT to unravel the networks and roles of different human and non-human agencies in the bamboo shoot processing industry in Manipur, India. They found that frugal innovations are outcomes of negotiations among diverse actors as they attempt to extend their networks and maintained their complex relation during the process of translation. At a conceptual level, they argue that the basic premises of ANT can be instrumental to expand the knowledge on the processes behind frugal innovations in the informal sector, and the various human and non-human actors involved.

The article by Altamirano and Van Beers departs from innovation management theory, testing the assumption that frugal innovations are specifically designed for resource-constrained environments. Their article looks into the effects of mobile phone technology-induced frugal innovations on resource constraints, and how these influence productivity, public services provision, and inclusiveness. These effects are illustrated by two particular services that use the M-Pesa payment system in Kenya: an agricultural micro-insurance through mobile phones, and M-Farm, a market access service for small farmers. The results reveal positive impacts on private sector productivity and public services provisions. With regard to inclusiveness, the conclusion is that - in the short term - the application of information technology-induced frugal innovations will not be inclusive, but in the longer term, the inclusiveness of these innovations can be expected to increase.

The issue of polycentric innovation and who benefits from it is central to the article by Krishna and Foster. They investigate the endogenous relationship between small-scale innovations and participation in global value chains (GVCs), drawing on a survey of 320 fresh fruit farmers and 55 interviews in Kenya. They present a novel method to quantify small-scale (frugal) agricultural innovations, which either emanate from meeting standard requirements or evolve from local contexts (and are less codified). The article delves into the agency of the farmer in polycentric innovations, and the conclusion is that this agency is limited within GVCs due to skewed power asymmetries, and the lack of involvement of farmers in setting standards. The article contributes to the growing debate around 'who frugal innovation should be for' and 'what does frugal innovation do for the poor.'

The last article in this special issue by Rosca et al brings our attention to a dimension which is largely missing in the current frugal innovation and development debate, namely ecological sustainability. The need to design and produce affordable products and services in order to be able to penetrate BoP markets and/or to reach out to poor people may well lead to a 'race to the bottom' in which environmental standards are put aside. Through a systematic literature review, the paper investigates the current discussion on the environmental dimensions of frugal innovations, concluding that this discussion is scarcely to be found, and more attention for the sustainability agenda is needed to understand the full developmental potential of frugal innovation.

Together, the articles in this special issue show how - from various disciplinary backgrounds - development research can be well positioned to critically explore the developmental relevance of frugal innovations, and to identify under what conditions such innovation processes are more likely to contribute to more sustainable and more inclusive developmental outcomes. The phenomenon of frugal innovation allows for multidisciplinary research, which we consider a sine qua non to adequately investigate the developmental relevance of frugal innovation. 


\section{Looking Forward}

From various disciplinary and thematic entries, the articles in this special issue assert the relevance the of frugal innovation to development studies, and together, the articles set the contours for a research agenda on frugal innovation and development. In this section, we briefly look forward by highlighting two key global change processes that we think will increasingly influence the frugal innovation and development research agenda in the years to come. Firstly, the global diffusion of digital technologies originating from the current industrial revolution, which is the first techno-economic paradigm shift that almost simultaneously takes place in developed and developing countries, and possibly even faster and more disruptively in the latter. Secondly, population dynamics which will not only affect global demand, but will also raise huge developmental challenges.

\section{Global Diffusion of Digital Technologies}

The 4th Industrial revolution, broadly defined as the current and developing environment in which disruptive technologies and trends such as the Internet of Things (IoT), robotics, virtual reality (VR), and artificial intelligence (AI) are changing the way we live and work (Schwab, 2017), and the preceding or underlying digital revolution (the development of computers and information technology), have raised renewed interest among development scholars and policy makers for the role of innovation and technology in development. For a long time, the dominant discourse has been that it is more efficient for developing countries and domestic firms to acquire foreign technology created in industrialized countries, because innovation is costly, risky, and path-dependent (Fu et al, 2011). The basic idea was that if innovations were easy to diffuse and adopt regardless of their nature and type, a developing country could catch up rapidly by absorbing the most advanced technologies through various transmission mechanisms including international trade, foreign direct investment (FDI), migration, international research collaboration, and integration in GVCs (Pietrobelli, 1996, Fu et al, 2011). In due course, many developing countries opened up their markets to attract FDI and to import the latest technologies, and invested in foreign education of students and international research collaboration.

The policies aimed to gain from technology diffusion and adoption met with several difficulties though. One is that technology diffusion and adoption is not costless and unconditional (Fu et al, 2011). The speed of diffusion and adoption depends on local firms' absorptive capacity and complementary assets (ibid.) And only in the presence of local innovation capacity will multinational enterprises adopt a more integrated innovation practice, which has greater linkages with the local economy and thereby enables greater opportunities of knowledge transfer (Franco et al, 2011). In addition, technical change is often biased in a particular direction; foreign knowledge, technologies, and innovations developed in industrialized countries may not be appropriate to the economic and social conditions in developing countries (Acemoglu, 2002). Moreover, it cannot be assumed that private interests of multinationals coincide with the social interests of the host counties (Lall and Urata, 2003). Among others, Fu et al conclude that "studies largely fail to provide convincing evidence indicating significant positive technological transfer and spill-over effect of FDI on the local firms." (Fu et al, 2011, p. 1204).

Part of the explanation as to why 'catching up' became such a popular and dominant discourse has been the underlying assumption that innovation in developing countries hardly or 
insufficiently took place, and that local firms were barely involved in innovation and technology development. For most economies and firms this may have been true for breakthrough, disruptive innovations; but more often than not, innovation comes from the cumulative effect of implementing small-scale ideas over prolonged periods of time, as we have also argued above. These sorts of innovation, which in developing countries predominantly take place in the informal sector, have - as we have also argued - for a long time been 'below the radar' in recent development studies. Still, mediating between foreign technology and indigenous innovation might be evident from country level perspective but maybe not so much from the perspective of local firms. On the one hand the North-South technology gap in several industries remain remarkably persistent ( $\mathrm{Fu}$ et al, 2011), and hard for individual local firms to overcome. On the other hand, establishing links between informal sector firms and formal sector firms - either foreign or local - is not so self-evident. The consequence for local innovative firms might be a 'locked in' or path-dependent trajectory, which prevents them from embarking on trajectories for further innovation and growth.

Do these conclusions need revision in the light of the new developments in the digital era? One of the biggest changes in the innovation landscape in the many societies in the Global South has been the fast spread of digital technologies. These digital technologies - the internet, mobile phones, and all the other tools to collect, store, analyze, and share information digitally - have spread quickly in developing countries. For example, nearly 70 percent of the bottom fifth in income of the population in developing countries owns a mobile phone, and it is estimated that more people in developing countries have a mobile phone than having access to clean water (World Bank, 2016). And the number of internet users has more than tripled in a decade - from 1 billion in 2005 to an estimated 3.2 billion at the end of 2015 (World Bank, 2016). Strong regional and inter-country differences exist though with marked differences between developing countries and the LDCs, and between Africa and other regions in the Global South (see Table 1). Although Africa is portrayed in the media as the continent where the spread of mobile and digital technology is currently the most spectacular, this does hide the fact that in terms of mobile subscriptions, computer possession, internet access, and mobile broadband subscriptions, Africa is behind other regions. Still, when comparing country figures, African countries like Kenya, Nigeria, and South Africa show on average the same figures as India. The presented figures are only indicative that interregional comparisons are relative, and that digital technologies are unevenly spread across the Global South.

Besides the fast rise and spread of mobile phone technology and internet, the World Bank (2016) identifies five developments in digital technology which are expected to spread quickly to the developing world: Artificial Intelligence (AI), robotics, autonomous vehicles (including drones), the Internet of Things (IoT), and 3D printing. Numerous examples of applications of these technologies can be found throughout the developing world, for example in education, health, farming, and in banking and insurance. If we look at these technology developments through a frugal innovation and development lens, several features stand out. Many products and services can be made frugal because of the availability of new digital technologies. Instead of the high investments needed to develop 'hardware,' much of this hardware can be replaced by using software, with much lower fixed costs and investments involved. For instance, smartphone apps can be used to measure body temperature or eye deficiencies, instead of using thermometers or expensive eye measurement apparatus; digitalized weather stations cost a fraction of conventional measurement systems. There are still fixed costs involved in building the app or station, but the marginal cost of adding another one has become tiny. This gives rise to increasing returns to scale, which stimulate new business and delivery models, and makes 
Table 1: Subscription and access to digital technology across regions

\begin{tabular}{|c|c|c|c|c|}
\hline & $\begin{array}{c}\text { Mobile subscriptions } \\
\text { per } 100 \text { inhabitants }\end{array}$ & $\begin{array}{c}\text { Per cent of } \\
\text { households with } \\
\text { computer }\end{array}$ & $\begin{array}{l}\text { Households with } \\
\text { internet access }\end{array}$ & $\begin{array}{c}\text { Broadband } \\
\text { subscriptions mobile } \\
\text { per } 100 \text { inhabitants }\end{array}$ \\
\hline World & 98.6 & 45.6 & 49.6 & 44.2 \\
\hline Developed & 125.7 & 81.0 & 81.3 & 87.1 \\
\hline Developing & 93.0 & 33.1 & 37.6 & 35.3 \\
\hline LDCs & 68.4 & 7.1 & 9.7 & 13.8 \\
\hline Africa & 76.2 & 9.7 & 9.7 & 19.0 \\
\hline Americas & 111.8 & 65.4 & 65.4 & 74.6 \\
\hline Arab States & 110.5 & 41.9 & 41.9 & 42.8 \\
\hline Asia and Pacific & 93.0 & 36.0 & 36.0 & 37.7 \\
\hline CIS & 142.8 & 64.4 & 64.4 & 51.2 \\
\hline Europe & 119.8 & 79.8 & 79.8 & 72.8 \\
\hline Brazil & 126.6 & 53.3 & 54.5 & 88.6 \\
\hline China & 93.2 & 49.6 & 54.2 & 56.0 \\
\hline India & 78.8 & 14.1 & 20.0 & 9.4 \\
\hline Indonesia & 132.4 & 18.7 & 38.4 & 42.1 \\
\hline Mexico & 85.3 & 44.9 & 39.2 & 50.4 \\
\hline Kenya & 80.7 & 13.1 & 19.6 & 15.5 \\
\hline Nigeria & 82.2 & 9.8 & 11.4 & 20.9 \\
\hline South Africa & 159.2 & 23.4 & 50.6 & 59.5 \\
\hline
\end{tabular}

Source: Data derived from Global ICT Development Index (2016).

products and services affordable and available to lower income segments of the population, also those living in remote areas.

In addition, the mobile and internet technology, but also the Internet of Things, have lowered the entry level for entrepreneurs in the Global South to become engaged in innovation. In many economic sectors, the costs of innovation have declined dramatically. Whereas in the past laboratories, staff, and expensive equipment were needed, nowadays one person with a laptop can design and develop innovative products and services and run his or her business likewise from his or her own location. Globally, there has been a rise in spaces where people can gather to build and learn with electronics, software, and digital fabrication. Known as makerspaces, FabLabs, iHubs, etc., these spaces have democratized access to tools, and empowered participants to build and learn on their own. These developments have opened new opportunities for entrepreneurs in the Global South to gain relatively easy access to technologies that could help them to embark on innovation-driven growth trajectories, and opened up new opportunities for those who aim to serve their own or foreign markets (see Heilbron et al, 2017), and these trajectories will probably be different from the trajectories that have been followed in the Global North. The new technologies can allow for the creation and development of context-specific solutions, affordable, and with good enough quality, typically basic features of frugal innovation.

But we need to remain cautious. Some scholars speak about a democratization of technology across regions and societies (Evans, 2011, Howard, 2015, Rifkin, 2011). In contrast, the World Bank (2016) concludes that despite many individual success stories, the effect of technology on global productivity, the expansion of opportunity for the poor and the middle class has so far been less than expected. Digital technologies have been spreading, but digital dividends are not spread equally over the global population or several reasons (World Bank, 2016). Nearly 60 
percent of the world's people are still offline and cannot participate in the digital economy in any meaningful way. Public sector investments in digital technologies, in the absence of accountable institutions, amplify the voice of elites, which can result in policy capture and greater state control. And because the economics of the internet favor natural monopolies, the absence of a competitive business environment can result in more concentrated markets, benefiting incumbent firms. Not surprisingly, the better educated, well connected, and more capable have received most of the benefits while a majority of people lag behind (World Bank, 2016). Given that many of today's frugal innovations build upon digital technology and its various applications, this raises urgent questions and asks for critical research on who reaps the benefits of frugal innovation and who does not; and what will be done with these benefits? Frugal innovation research definitely needs to delve into these urgent questions if it aims to contribute to further insights on the developmental relevance of frugal innovations.

\section{Population Dynamics}

A second global trend which will further assert the developmental relevance of frugal innovation is population dynamics. Three sub-trends are particularly relevant: population growth, urbanization, and displacement because of turmoil and (natural) calamities.

Recent projections forecast that the world population will continue to grow for decades to come. This is the result of 'population momentum': because of improved survival rates and past high fertility levels, there are more women of reproductive age today. The recent past has seen enormous changes in fertility rates and life expectancy. In the early 1970s, women had on average 4.5 children each; by 2015 , total fertility for the world had fallen to below 2.5 children per woman (United Nations DES/PD, 2017). Meanwhile, average global lifespans have risen, from 64.6 years in the early 1990s to 70.8 years today (ibid.). After 2060 population growth will almost exclusively be driven by fertility levels in the world's least developed countries. The combined population of the LDCs, roughly one billion in 2017, is projected to increase by 33 per cent between 2017 and 2030, and then to reach 1.9 billion persons in 2050. Beyond 2050, Africa is projected to be the main contributor to global population growth (see also Dietz, 2017).

In addition, the world is seeing high levels of urbanization. In today's increasingly global and interconnected world, over half of the world's population (54 per cent) now lives in urban areas, up from 30 per cent in 1950. The coming decades will bring further profound changes to the size and spatial distribution of the global population such that the world's population in 2050 is projected to be 66 per cent urban (UN DES/PD, 2015). The global urban population is projected to grow by 2.5 billion urban dwellers between 2014 and 2050, with nearly 90 per cent of the increase concentrated in Asia and Africa (ibid.). Over the coming decades, the level of urbanization is expected to increase in all regions, with Africa and Asia urbanizing faster than the rest. In 2014, the proportion urban in Asia and Africa was increasing at rates of 1.5 per cent and 1.1 per cent per annum, respectively (ibid.). Nevertheless, these two regions, which are projected to reach 56 per cent and 64 per cent urban by mid-century, respectively, are still expected to be less urbanized than other regions of the world (ibid.).

A third population-related development is the significant and rising level of internal displacements and refugees by conflict, violence, and natural disasters. The UNCHR estimates the number of refugees in 2016 at 22.5 million (UNHCR, 2017). In addition, 31.1 million people were internally displaced by conflict, violence, and disasters in 2016 of which 24.2 million by natural disasters and 6.9 million by conflict and violence (IDMC, 2017). The number 
of displacements has almost doubled since 2000. With regard to violence and conflict-related displacements, Sub-Saharan Africa overtook the Middle East as the region most affected. South and East Asia were the regions most affected when it comes to displacements caused by natural disasters. Generally, low and lower middle-income countries bear the brunt of internal displacement every year, given the high-risk environments in these countries characterized by low coping capacity, high levels of socio-economic vulnerability, and high exposure to natural and man-made hazards.

These population dynamics relate in several ways to frugal innovation and its developmental relevance. First, the claim made in the innovation management literature that there might be an increased consumer demand for frugal products and services seems to be justified. Due to (still) high population growth, combined with rising living standards in many countries in the Global South, the low and (emerging) middle-income classes represent a growing BoP market, which is estimated at five trillion US dollars in purchasing power parity. India, Nigeria, China, Indonesia, and South Africa have been identified as the current top BoP markets (Euromonitor International, 2017). Brazil, Mexico, Turkey, and Russia follow closely. Market research has shown that people belonging to these income classes are receptive and willing to spend money on quality products, provided these are suitable, have well enough quality and are reasonably priced (Nakata and Weidner, 2012, Prahalad, 2005). Frugal innovations may well respond to the aspirations of this group of consumers.

At the same time, it is projected that size of the middle class globally could increase from 1.8 billion people to 3.2 billion by 2020, and to 4.9 billion by 2030 (Kharas, 2010). Almost all of this growth ( 85 per cent) comes from Asia. Equally striking is the growth in purchasing power of the middle class. Globally, demand from the middle class may grow from USD21 trillion to USD56 trillion by 2030 (ibid.). Again, over 80 per cent of the growth in demand comes from Asia (ibid.). This shift in demand may well be disruptive for existing supply chains. It does not tell us anything about the nature of this demand in terms of what products will be consumed and where they will be made, but if the global middle class is defined as all those living in households with daily per capita incomes of between USD10 and USD100 in PPP terms, the income elasticity of consumption appears to be greater than one, and a range of new goods and services is demanded. While for the upper middle classes frugal products and services might not appeal to their aspirations and status, this might well be for the lower middle class (for example, those who live with daily per capita incomes between 10 and 25 USD in PPP terms).

Apart from an increased demand in the Global South for frugal products and services, the identified population dynamics trends have far-reaching implications for development. They affect economic development, employment, income distribution, poverty, and social protections. They also affect efforts to ensure universal access to health care, education, housing, sanitation, water, food, and energy, as well as people's environmental footprint and vulnerability to natural hazards. To respond to these challenges, policies are needed that prepare for better income and employment opportunities in both urban and rural areas; expanding the necessary infrastructure for water and sanitation, energy, transportation, information and communications; ensuring equal access to services, like education and health care; developing sufficient quality housing and preserving the natural assets within urban and rural areas. Given the challenges ahead, and taking into account the national, regional or local budgets of governmental bodies in most developing countries, frugal innovation could play an immense role in ensuring employment, addressing poverty, and providing adequate public services delivery, be it in urban slums, remote rural areas or settlements or camps for displaced or refugees. The main question for development research becomes then under what conditions 
can these frugal innovations play this role, taking into account sustainability and inclusiveness issues.

\section{Concluding Remarks}

In this introductory article to the special issue, we have pointed out some of the reasons why and where the emerging body of research and literature on frugal innovation has relevance for development and development research. Frugal innovations are often the result of locally embedded 'bricolage' and adaptive livelihood strategies, of local companies, of social entrepreneurs or NGOs, or of international corporates trying to capture the 'fortune' at the Base of the Pyramid. In this 'messy' and dynamic reality, the longer-term developmental implications of such innovation processes do not often get sufficient attention. Questions like: 'who can get access to these new opportunities' and 'who owns the platform and might be able to monopolize the benefits?' are usually not raised, but are of crucial importance in terms of ensuring more progressive longer-term developmental impacts of frugal innovations. The various contributions in this special issue aim to explore and investigate these questions further and together set the contours for a possible research agenda.

In addition, we have argued that the changing innovation landscape in economies and societies in the Global South - triggered among others by the global diffusion of digital technologies and the challenges raised by population dynamics - raises intriguing questions on what this implies for innovation; and, more generally, what is implied for the development trajectories in this part of the world, and what the role of frugal innovation is in these trajectories. In answering these questions, studies on frugal innovation can - among others relate to and build upon the history of thought on innovation and technology in development studies, and at the same time give a new impetus to this body of knowledge.

The questions on frugal innovation and its developmental relevance are all the more urgent because of a third global trend that has not been given specific attention in this introductory article: an increasingly widespread awareness of the ultimate global consequences of environmental pollution and resource depletion, leading to an urgent need to invest in a global green transformation with low carbon footprints, and production and consumption patterns based more systematically on circularity and usage instead of relying on mass production, ownership, and waste creation. Among others, this awareness largely explains the call for frugality in western societies, which is mainly driven by environmental concerns, e.g., recycling, energy reduction, solid waste management, and minimizing carbon footprints. Contemporary frugality movements like the 'voluntary simplicity movement' (Bouckaert et al, 2011) and 'ethical consumerism' combine more traditional virtues with environmentalism. A contemporary translation of frugality can also be found in discussions on circular economies, renewable energy, and the energy transition, and among maker and prosumer movements in various places across the globe. However, it seems quite unlikely to expect that many among those groups in developing countries - who are among the 'new' middle classes - will follow such a voluntary constraint perspective. The article by Rosca et al in this special issue is a first exploration of and plea for a research agenda that aims to better understand the relationship between frugal innovation, global (inclusive) development, and ecological sustainability.

For the questions raised in this introductory article, we need to further develop theories and a research agenda which can contribute to an empirically based, positivist, and critical analysis of how frugal innovation and development relate, and what this implies for people (innovators, entrepreneurs, users, men, women, young, old, etc.) involved. A multidisciplinary approach, 
which is also adopted in this special issue, is considered pivotal in this research agenda. Instead of asserting its developmental relevance a priori, we need to systematically and critically investigate how frugal innovation manifestations in different parts of the world relate to development to be better able to assess its transformational or developmental potential. Therewith, development and (frugal) innovation are autonomous and also partially contradictory and conflicting processes, whose outcomes cannot be predicted. In this sense, it is also worthwhile to remember and be informed by the four key questions that Henry Bernstein (2010) finds pivotal for a critical research agenda in political economy: Who owns what? Who does what? Who gets what? What do they do with the created surplus wealth?

\section{Acknowledgements}

The papers in this special issue were first presented at the international workshop 'When Can Frugal Innovations Become Inclusive Innovations?' held in The Hague, The Netherlands on 26 and 27 November 2015. The workshop was organized by the Centre for Frugal Innovation in Africa (CFIA) - a Dutch research centre established by Leiden University, Delft University of Technology and Erasmus University Rotterdam - in cooperation with the European Association for Development Institutes (EADI). Papers were subsequently revised, and submitted to a double-blind refereeing process. We are indebted to Iva Peša for her valuable contributions to the organization of the workshop and the preparatory stage which has led to this special issue. We are grateful to the journal's Editorial Team, in particular Natalia Lorenzoni (Managing Editor) for facilitating the publication of this issue. We also thank the many EJDR referees for their role in the evaluation of the papers.

\section{Note}

1. Next to these two discourses, there is also an emerging strand of literature on how people in more wealthy settings in industrialized countries sometimes consciously choose more frugal life styles, like in the 'voluntary simplicity movement' (Bouckaert et al, 2011). See also the concluding remarks in this introductory article.

\section{References}

Acemoglu, D. (2002) Technical change, inequality, and the labor market. Journal of Economic Literature 40(1): 7-72.

Bernstein, H. (2010) Class Dynamics of Agrarian Change. Halifax and Fernwood, MA: Kumarian.

Bhaduri, S. (2016) Frugal Innovation by the 'small and the marginal': An alternative discourse on innovation and development. Inaugural lecture Prince Claus Chair in Development and Equity, 23 May 2016, Erasmus University Rotterdam.

Bhatti, Y. (2012) What is frugal? What is innovation? Towards a theory of frugal innovation. SSRN Working Paper Series, Oxford Centre for Entrepreneurship and Innovation.

Bouckaert, L. Opdebeeck, H. and Zsolnai, L. (2011) Frugality. In: L. Bouckaert and L. Zsolnai (eds.) Handbook of Spirituality and Business. London: Palgrave Macmillan, pp. 269-276.

Chambers, R. and Conway, G.R. (1992) Sustainable Rural Livelihoods: Practical Concepts for the 21st Century. Discussion Paper 296, Brighton, UK: Institute of Development Studies.

Chataway, J., Hanlin R. and Kaplinsky. R. (2014) Inclusive Innovation: An architecture for policy development. Innovation and Development 4(1): 33-54.

De Haan, L. and Zoomers, A. (2005) Exploring the frontiers of livelihoods research. Development and Change 36(1): 27-47. 
Dietz, T. (2017) Africa; still a silver lining. Valedictory lecture given at Leiden University on Monday, September 25, 2017. http://www.ascleiden.nl/sites/default/files/afscheidscollege_dietz_web.pdf, accessed 17 October 2017.

Dolan, C. and Rajak, D. (2016) Remaking Africa's informal economies: Youth, entrepreneurship and the promise of inclusion at the bottom of the pyramid. Journal of Development Studies 52(4): 514-529.

Dolan, C. (2013) Capital's new frontier: From 'unusable' economies to bottom of the pyramid markets in Africa. African Studies Review 56(3): 123-146.

Ellis, F. (2000) Rural Livelihoods and Diversity in Developing Countries. Oxford: Oxford University Press.

Euromonitor International (2017) http://blog.euromonitor.com/2017/03/top-5-bottom-pyramid-marketsdiverse-spending-patterns-future-potential.html, accessed 19 October 2017.

Evans, D. (2011) The Internet of Things; How the Next Evolution of the Internet Is Changing Everything. White Paper, CISCO. https://www.cisco.com/c/dam/en_us/about/ac79/docs/innov/IoT_IBSG_ 0411FINAL.pdf.

Franco, E., Ray, S. and Ray, P.K. (2011) Patterns of innovation practices of multinational affiliates in emerging economies: Evidence from Brazil and India. World Development 39(7): 1249-1260.

Fransman, M. and King, K. (eds.) (1984) Technological Capability in the Third World. London and Basingstoke: The Macmillan Press Ltd.

Fu, X., Pietrobelli, C., and Soete, L. (2011) The role of foreign technology and indigenous innovation in the emerging economies: Technological change and catching-up. World Development 39(7): $1204-1212$.

Gewald, J.B., Leliveld, A. and Peša I. (eds.) (2012) Transforming innovations in Africa: Explorative studies on appropriation in African societies. Leiden: Brill.

Global ICT Development Index (2016) http://www.itu.int/net4/ITU-D/idi/2016/, accessed 16 October 2017.

Heilbron, M., Leliveld, A. and Knorringa, P. (2017) Innovation as a key to success? Case studies of innovative start-ups in Kenya and Nigeria. In: A. Akinyoade, T. Dietz and C. Uche (eds.) Entrepreneurship in Africa. African Dynamics, No. 15, Leiden: Brill, pp. 95-122.

Hahn, R. (2012) Inclusive business, human rights and the dignity of the poor: A glance beyond economic impacts of adapted business models. Business Ethics: A European Review 21(1): 47-63.

Howard, Philip N. (2015) Pax Technica: How the Internet of Things May Set Us Free or Lock Us Up. New Haven, CT: Yale Press.

Internal Displacement Monitoring Centre (IDMC) (2017) Global Report on Internal Displacement. Geneva: IDMC.

Kaplinsky, R. (2011) Schumacher meets Schumpeter: Appropriate technology below the radar. Research Policy 40(2): 193-203.

Kharas, H. (2010) The Emerging Middle Class in Developing Countries. Working Paper No. 285, OECD Development Centre. Paris: OECD.

Knorringa, P., Peša, I., Leliveld, A. and Van Beers, C. (2016) Frugal innovation and development: Aides or adversaries? European Journal of Development Research 28: 143-153.

Lall, S. (1992) Technological capabilities and industrialization. World Development 20(2): 165-186.

Lall, S. and Urata, S. (2003) Competitiveness, FDI and Technological Activity in East Asia. Cheltenham: Edward Elgar Publishing.

Leliveld, A. (2017) Revisiting survival strategies from a frugal innovation perspective: A research idea. In: W. van Beek, J. Damen and D. Foeken (eds.) The Face of Africa; Essays in Honour of Ton Dietz. ASCL Occasional Publications 28, Leiden: African Studies Centre Leiden, pp. 91-100.

Lévi-Strauss, C. (1962) The Savage Mind. Chicago: Chicago University Press.

Lundvall, B.A., Joseph, K.J., Chaminade, C. and Vang, J. (eds.) (2011) Handbook of Innovation Systems and Developing Countries; Building Domestic Capabilities in a Global Setting. Cheltenham: Edward Elgar Publishing Inc.

Meagher, K. and Lindell, I. (2013) ASR FORUM: engaging with African informal economies: social inclusion or adverse incorporation? Introduction. African Studies Review 56(3): 57-76.

Nakata, C. and Weidner, K. (2012) Enhancing new product adoption at the base of the pyramid: A contextualized model. Journal of Product Innovation Management 29(1): 21-32.

Obeng-Odooma, F. and Ameyawb, S. (2014) A new informal economy in Africa: The case of Ghana. African Journal of Science, Technology, Innovation and Development 6(3): 223-230. 
Pedersen, P.O. and McCormick, D. (1999) African business systems in a globalising world. The Journal of Modern African Studies 37(1): 109-135.

Pietrobelli, C. (1996) Emerging Forms of Technological Cooperation: The Case for Technology Partnerships - Inner Logic, Examples and Enabling Environment. Science and Technology Issues. Geneva: UNCTAD - United Nations.

Prahalad, C.K. and Hall, S.L. (2002) The fortune at the bottom of the pyramid. Strategy + Business 26(1): $1-14$.

Prahalad, C.K. (2005) The Fortune at the Bottom of the Pyramid. Upper Saddle River, NJ: Wharton School Publishing.

Prahalad, C.K. (2012) Bottom of the pyramid as a source of breakthrough innovations. Journal of Product Innovation Management 29(1): 6-12.

Radjou, N. (2009) Polycentric Innovation: The New Global Innovation Agenda for MNCs. Harvard Business Review online article 5 November 2009.

Radjou, N., Prabhu, J. and Ahuja, S. (2012) Jugaad Innovation: A Frugal and Flexible Approach to Innovation for the 21st Century. India: Random House.

Radjou, N. and Prabhu, J. (2015) Frugal Innovation: How to do More with Less. London: Profile Books.

Rao, B.C. (2013) How Disruptive is Frugal? Technology in Society 35(1): 65-73.

Rifkin, J. (2011) The Third Industrial Revolution: How Lateral Power is Transforming Energy, the Economy, and the World. New York: Palgrave Macmillan Ltd.

Schwab, K. (2017) The Fourth Industrial Revolution. Beverly Hills: Random House USA Inc.

Schumacher, E.F. (1973) Small is Beautiful: Economics as if People Mattered. London: Blond and Briggs.

Scoones, I. (2009). Livelihoods perspectives and rural development. The Journal of Peasant Studies 36(1): $171-196$.

Seyfang, G. and Smith, A. (2007) Grassroots innovations for sustainable development: Towards a new research and policy agenda. Environmental Politics 16: 584-603.

The Economist (2010) First break all the rules. 15 April 2010.

Tiwari, R., Fischer, L. and Kalogerakis, K. (2016) Frugal Innovation in Scholarly and Social Discourse: An Assessment of Trends and Potential Societal Implications. Working Paper. Project Potenziale Frugaler Innovationen. https://tubdok.tub.tuhh.de/bitstream/11420/1291/1/Tiwari_et_al_2016_ Frugal_Innovation_BMBF_ITA.pdf, accessed 10 October 2017.

UNHCR (2017) Global Trends; Forced Displacement in 2016. Geneva: UNHCR.

United Nations, Department of Economic and Social Affairs, Population Division (2017) World Population Prospects: The 2017 Revision, Key Findings and Advance Tables. ESA/P/WP/248.

United Nations, Department of Economic and Social Affairs, Population Division (2015) World Urbanization Prospects: The 2014 Revision. ST/ESA/SER.A/366.

World Bank (2016) World Development Report 2016: Digital Dividends. Washington DC: World Bank.

Zeschky, M.B., Winterhalter, S. and Gassmann, O. (2014) From cost to frugal and reverse innovation: Mapping the field and implications for global competitiveness. Research-Technology Management 57(4): 20-27.

Zeschky, M., Widenmayer, B. and Gassmann, O. (2011) Frugal innovation in emerging markets. Research-Technology Management 54(4): 38-45. 